\title{
Aspects of appropriate feeding of cows for production of milk enriched in the fatty acids, EPA and DHA. A review
}

\author{
M. Zymon ${ }^{1,3}$, J. Strzetelski ${ }^{1}$ and G. Skrzyński ${ }^{2}$ \\ ${ }^{1}$ National Research Institute of Animal Production, Department of Animal Nutrition and Feed Science \\ 32-083 Balice, Poland \\ 2University of Agriculture in Krakow, Faculty of Animal Science \\ Al. Mickiewicza 24/28, 30-059 Krakow, Poland
}

KEY WORDS: cow, milk, fish oil, ruminal biohydrogenation, long-chain fatty acids

Received: 22 June 2012

Revised: 31 January 2014

Accepted: 12 June 2014

${ }^{3}$ Corresponding author:

e-mail: monika.zymon@izoo.krakow.pl

\begin{abstract}
Eicosapentaenoic (EPA) and docosahexaenoic (DHA) acids are long-chain n-3 polyunsaturated fatty acids that are essential for human health. They play an important role in prevention of heart disease and some cancers. The richest source of EPA and DHA are fish and marine products, but in Poland the consumption of fish is slightly declining. Milk enriched with EPA and DHA could be an alternative and effective means of increasing the consumption of these fatty acids. EPA and DHA could be transferred to milk from a cow's diet or synthesized from their precursor, a-linolenic acid (LNA). Increasing the dietary supply of EPA and DHA, or LNA, has a limited effect, however, due to the extensive biohydrogenation of these fatty acids in the rumen and low uptake by the mammary gland. Feeding protected sources of n-3 polyunsaturated fatty acids does increase the EPA and DHA content of total fatty acids, although absolute levels are relatively low, and results in an increased concentration of conjugated linoleic acid in milk. Issues that need to be researched include the development of a suitable oil supplement and a reliable means of protecting it from rumen biohydrogenation.
\end{abstract}

\section{Introduction}

In recent years, in highly developed countries in particular, opinions on human nutrition have shifted in a large part due to increased nutritional awareness among consumers. Food is no longer seen only as a source of nutrients that satisfy the body's needs. It is the food's health-promoting properties that are attracting increasing interest among consumers.

A special role in the human diet is played by foods of animal origin. Milk, in particular milk fat, has become the focus of attention for scientists, physicians, technologists, and consumers alike. Milk and milk products are an integral and essential part of the human diet, with milk fat being one of its most valuable constituents. According to Hippocrates, 'milk is nature's most perfect and complete food'. Due to the presence of several bioactive components, it plays an important role in preventing, and even curing, various diseases of modern civilization (Akalin et al., 2006). The polyunsaturated fatty acids found in milk fat are mainly linoleic and 
linolenic acids. The enzymatic conversion of linolenic acid into its long-chain derivatives, i.e. the unsaturated fatty acids EPA (eicosapentaenoic acid) and DHA (docosahexaenoic acid) that are essential to human health, is often limited by metabolic factors. The conversion of n-3 acids in the human body is, however, most often blocked by excess dietary intake of omega- 6 acids. For this reason it is necessary to supplement the diet with unsaturated omega-3 fatty acids, which should be an indispensable part of the human diet due to their health-promoting properties. Eicosapentaenoic (C20:5) and docosahexaenoic acids (C22:6) are essential fatty acids of the n-3 series. These acids can be supplied to the body through the diet. Their main source is oil from fish and marine animals, but they can also be synthesized from ALA ( $\alpha$-linolenic acid, C18:3) (Givens et al., 2000). Many studies conducted in recent years have shown that n-3 PUFA have a beneficial effect in many diseases and their increased dietary intake may help to lower the incidence of many lifestyle diseases, including coronary heart disease (Kromhout, 1989). A deficiency of n-3 PUFA has also been implicated in other chronic disorders, including hypertension, inflammatory diseases, neurological dysfunction, and depression. There is evidence indicating that n-3 fatty acids inhibit the growth of some cancer cells, in particular mammary tumours (Karmali, 1989; Noguchi et al., 1995), while n-6 fatty acids stimulate tumour growth. The anti-tumour effect of n-3 fatty acids was also observed in colon (Tsai et al., 1998) and prostate cancer cells (Rose and Connolly, 1991).

Today, many developed countries, including Poland, face health problems resulting from excessive consumption of fats with an undesirable composition. One indicator of the health quality of one's diet is the level of PUFA it contains. According to FAO/ WHO (1993), the n-6-to-n-3 fatty acid ratio should be $4: 1$ to $6: 1$, but not more than 10:1. In the diets of many countries, this ratio is considerably different from the desired values due to the excessive amounts of n- 6 fatty acids consumed in vegetable fats and deficiency of $\mathrm{n}-3$ fatty acids. It is now recommended that the intake of n-3 PUFA should be between 250 and $500 \mathrm{mg}$ per day (EFSA J., 2012), but the actual intake is much lower. An excellent dietary source of essential unsaturated omega-3 fatty acids, especially EPA and DHA, are fish oil. Regrettably, even though Poland is a seaside country, both fish consumption and the percentage of fish eaters in Poland are very low. The average Pole eats only about $12 \mathrm{~kg}$ of fish per year, which is in fact only $5 \mathrm{~kg}$ of edible parts (Kołodziejczyk, 2007;
Konieczny, 2010). In contrast, fat from milk and milk products is consumed more readily than fish oil and its composition can be modified to varying degrees by diet. It is therefore worth considering modifying the composition of milk lipids to increase the proportion of essential long-chain unsaturated fatty acids, EPA and DHA. This modification can be accomplished, among others, by feeding fish oil to dairy cows. The use of fish oil in cow nutrition has been investigated by many authors (e.g., Cant et al., 1997; Gulati et al., 1999; Keady et al., 2000; Offer et al., 2001; Abu-Ghazaleh et al., 2002, 2003). Dietary fish oil supplements were generally found to increase the content of omega-3 fatty acids in milk. Perhaps milk enriched in this way could help prevent the diseases of modern civilization if consumed in much greater amounts than fish.

The aim of this review is a discussion of the methodological and metabolic aspects of the nutritional methods currently used for the preparation of milk enriched with DHA and EPA. It is important to clarify the metabolic processes that effect the transfer of EPA and DHA from the diet to milk and those factors that may affect this transfer. Furthermore, the processes that control the conversion of $\alpha$-linolenic acid LNA to EPA and DHA in the cow and the possibility of increasing the EPA and DHA contents of the milk will be considered.

\section{EPA and DHA metabolism in dairy cows}

When supplemented to dairy cow diets, longchain fatty acids, i.e. EPA and DHA, have a low transfer rate into milk, which is probably due to their ruminal biohydrogenation and low intestinal digestibility. An important role in this process can also be played by lipoprotein lipase, which is a key enzyme of lipid metabolism. Fatty acids are transported to the mammary gland by plasma lipoproteins, which are not good substrates for mammary lipoprotein lipase. Furthermore, this enzyme may release EPA and DHA from triglycerides to a lesser extent, and mammary gland acyltransferases can have low affinity for these fatty acids. It may be that these acids are first distributed to other body tissues, for example muscle or adipose tissue (Rymer et al., 2003).

In contrast to monogastric animals, lipid metabolism in the rumen changes the fatty acid profile. The first step in the metabolism of dietary fats is ruminal lipolysis. Lipids extracted from the feed can be largely hydrolysed by enzymes of rumen bacteria: Anaerovibrio lipolytica and Butyrivibrio fibrisolvens (Harfoot and Hazlewood, 1997). The next step in the metabolism of lipids in the rumen is hydrogenation of unsaturated 18-carbon fatty 
cis-9, cis-12 C18:2

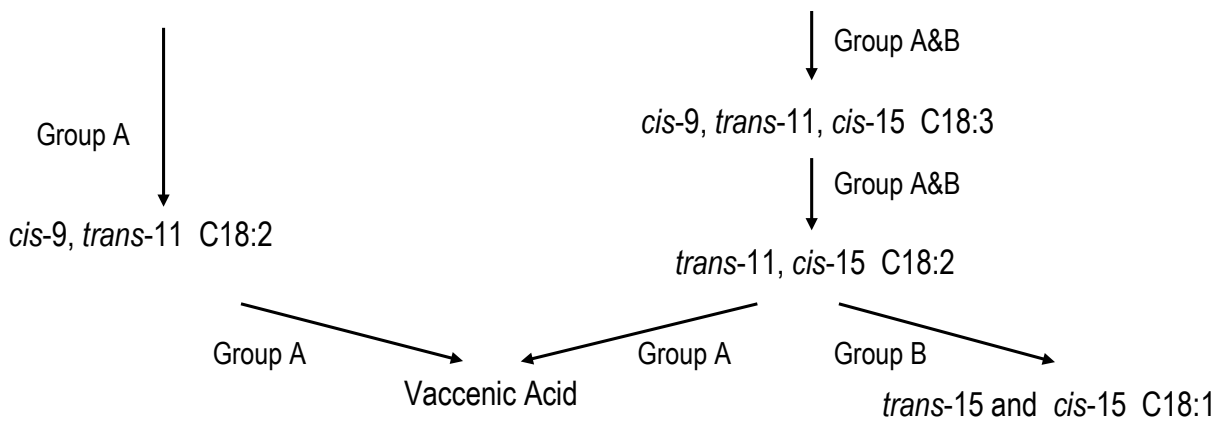

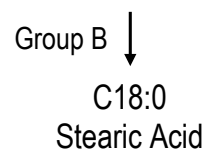

Figure 1. Biochemical pathways for the biohydrogenation of linoleic and linolenic acids in the rumen (Harfoot and Hazlewood, 1997)

acids into stearic acid. The main substrates are linoleic acid and linolenic acid, and the rate of hydrogenation increases with the degree of unsaturation (Harfoot and Hazlewood, 1997). The ruminal bacteria involved in hydrogenation have been classified into two groups, A and B, according to the metabolic pathway involved (Kemp and Lander, 1984). For complete hydrogenation of PUFA, both groups of bacteria are usually necessary. Group A comprises a plurality of bacteria able to hydrogenate PUFA into vaccenic acid; this groups includes Butyrivibrio fibrisolvens, Micrococcus sp. and Ruminococcus albus. Group B, including Fucocillus, participates mainly in hydrogenation of oleic acid, cis-9 C18:1, and its isomers into stearic acid. Two key biohydrogenation intermediates are trans-11 C18:1 vaccenic acid, formed from linoleic and linolenic acids, and cis-9, trans-11 conjugated linoleic acid (CLA), formed by biohydrogenation of linoleic acid. The biohydrogenation processes in the rumen, however, are complex and apart from the main pathway involving trans-11 C18:1 and cis-9, trans-11 CLA as intermediates, there must be many more routes.

Free fatty acids with 18 carbon atoms are largely biohydrogenated, but the fate of fatty acids with longer chains has not been adequately studied. Ashes et al. (1992) and Offer et al. (2001) observed that a considerable proportion of EPA and DHA is not hydrogenated because the serum and plasma levels of these acids significantly increased when they were added to sheep and cow diets. The same authors also found that the transfer rate of EPA and DHA from the diet into the duodenum is very limited if the fat is not protected from metabolic processes in the rumen. The course of fatty acid biohydrogentation was also found to change with increasing intake of fish oil. The proportion of $\mathrm{C} 18$ trans and $\mathrm{C} 18$ hydroxy fatty acids increases (Kitessa et al., 2001c) while the degree of their biohydrogenation decreases (Gulati et al., 1999). When added to the diets of cows, EPA and DHA disturb rumen metabolism and 10-hydroxystearic acid is formed (Kitessa et al., 2001b). The production of 10-hydroxystearic acid may arise from the hydration of oleic acid present in fish oil, and this may be due either to changes in the microbial population or a result of changes in biochemical pathways in an attempt by the rumen microorganisms to reduce the cytotoxic effects of highly unsaturated fatty acids (Kitessa et al., 2001b).

Doreau and Ferlay (1994) observed a small decline in the level of fatty acids in the rumen, which may result from limited absorption, especially of short-chain fatty acids, by rumen walls. It is also possible that part of the fatty acids was converted to ketone bodies in the ruminal epithelium, and another part was oxidized by the bacteria attached to the ruminal wall, using oxygen from epithelial cells (Rymer et al., 2003).

Unlike in monogastric animals, almost $90 \%$ of dietary fats in ruminants reach the duodenum as non-esterified fatty acids. Fatty acids that enter the small intestine in the form of triglycerides, glycolipids and phospholipids can be released by pancreatic lipases, glycolipases and phospholipases as free fatty acids, and then absorbed. Low duodenal $\mathrm{pH}$ does not provide optimum conditions for the activity of these enzymes, however (Arienti et al., 1974). It can therefore be assumed that triglycerides are absorbed more slowly than free fatty acids in the intestine of ruminants (Doreau and Ferlay, 1994). In small intestinal epithelial cells, fatty acids are 
esterified and triglycerides and phospholipids are incorporated into chylomicrons and very low density lipoproteins (VLDL) and transported through lymph. In theory, lipids can also be absorbed from the large intestine, but the degree of absorption is very low (Doreau and Ferlay, 1994).

In ruminants, the digestibility of individual fatty acids depends on chain length. Digestibility was found to be highest for $\mathrm{C} 16$ and $\mathrm{C} 18$ acids (about 0.8 ), and slightly lower for $\mathrm{C} 12, \mathrm{C} 14, \mathrm{C} 20$ and $\mathrm{C} 22$ acids $(0.65-0.70)$. It is generally believed that the digestibility of fatty acids increases with decreasing saturation (Doreau and Ferlay, 1994).

EPA and DHA that escape rumen metabolism are absorbed from the small intestine as lipoproteins and transported in the aqueous media of lymph and blood to different organs and tissues in which they are stored and/or subjected to further processes.

In traditional diets, EPA and DHA supplied preformed from the diet or from linolenic acid are preferentially incorporated into phospholipids in the muscle tissue of ruminants (Ashes et al., 1992; Wood et al., 1999), while the level of these acids in adipose tissue is low. Considerable amounts of EPA and DHA (up to $0.75 \mathrm{~g} \cdot 100 \mathrm{~g}^{-1}$ fat) were found in subcutaneous and omental fat when lambs received a ration containing $3 \mathrm{~g} \cdot \mathrm{kg}^{-1} \mathrm{DM}$ of rumen-protected tuna oil (Kitessa et al., 2001c). When the supply of dietary fish oil was increased ( 80 or $120 \mathrm{~g} \cdot \mathrm{kg}^{-1} \mathrm{DM}$ ), however, no EPA or DHA was found in subcutaneous adipose tissue (Ashes et al., 1992). Thus, the dietary level of long-chain PUFA affects lipid metabolism, although in ruminants the incorporation of long-chain n-3 PUFA into adipose tissue triglycerides is low. The reasons for this are not completely understood.
EPA and DHA found in plasma lipoprotein triglycerides can be used by the mammary gland once they are released as free fatty acids. This reaction is catalyzed by lipoprotein lipase. Because absorbed EPA and DHA are transported around the body as phospholipids associated with the high-density lipoprotein (HDL) fraction, and this fraction is not a good substrate for lipoprotein lipase, the uptake by the mammary gland of absorbed EPA and DHA is extremely low. The concentration of EPA and DHA in milk fat remains low, therefore, even when the diet is enriched with these fatty acids. It was observed, however, that these acids support ruminal production of conjugated linoleic acid (Griinari and Bauman, 1999), which is incorporated mainly into the adipose tissue and mammary triglycerides of cattle. Docosahexaenoic acid elevates trans-18:1 isomers, but is not directly converted into trans-18:1 isomers in ruminal batch cultures (Klein and Jenkins, 2011). The principal sources of preformed long-chain fatty acids for milk fat production are chylomicron and plasma very low density lipoprotein VLDL triglycerides, but they fail to incorporate EPA and DHA into their own triglycerides to a large extent (Chilliard, 1993; Offer et al., 2001). Perhaps this explains, why the degree of incorporation of these acids into milk triglycerides is low compared with other fatty acids, although it significantly increases when fish oil is added to the diet. When the dietary concentration of EPA and DHA is increased, their concentration in milk also increases, although the transfer rate of these acids from diet into milk is very low. Chilliard et al. (2000) observed, that the transfer rate of EPA and DHA into milk increased after duodenal infusion of fish oil. This shows that the main reason

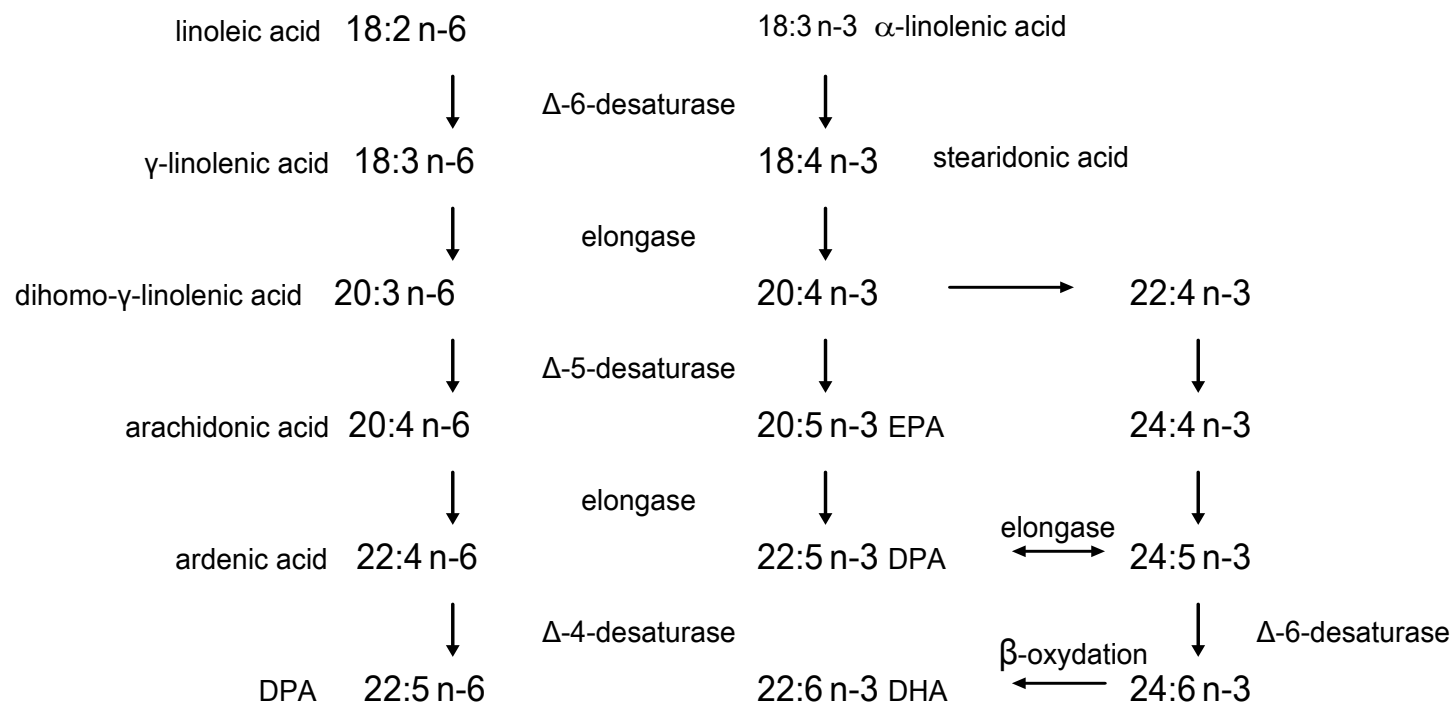

Figure 2. The metabolism of n-6 and n-3 essential fatty acids (Sprecher, 2000) 
for such a low transfer rate is the considerable ruminal biohydrogenation of these acids. Even when fatty acids bypass the rumen, the proportional transfer rate is still low, which suggests that most probably other mechanisms inhibit the transfer of EPA and DHA into milk, including the previously described form in which EPA and DHA enter the mammary gland (phospholipids associated with the high-density lipoprotein fraction).

It is possible, that the EPA and DHA present in milk arise from de novo synthesis of these acids from linolenic acid, and increased supply of this acid to the mammary gland may be an alternative way of increasing the concentration of EPA and DHA in milk. The conversion of linolenic acid to EPA is more efficient than its conversion to DHA (Wood et al., 1999), which suggests a lower ability to achieve final conversion from EPA to DHA.

\section{Increased supply of EPA and DHA}

It is, therefore, worthwhile to consider effective ways of increasing the EPA and DHA supply to increase the content of these acids in milk fat. Direct supplementation of the diet with EPA- and DHArich foods produces, in a sense, the desired effect. Addition of fish oil to the diet was generally found to increase the yield of EPA and DHA and to elevate the concentration of these acids in the fatty acid fraction of milk (Cant et al., 1997; Chilliard and Doreau, 1997; Franklin et al., 1999; Gulati et al., 1999; Keady et al., 2000; Offer et al., 2001; Zymon et al., 2007; Kim et al., 2008; Toral et al., 2010). When fish oil intake was low, no correlation was found between this intake and the yield of EPA, although a direct relationship, was noted when fish oil intake exceeded $428 \mathrm{~g}$ per day (Offer et al. 2001 ). In the cited studies, no relationship was observed between DHA concentrations in milk and fish oil intake. This may suggest more extensive ruminal biohydrogenation of DHA compared with EPA, or more extensive distribution into body tissues of DHA compared with EPA.

The use of fish oil as a feed supplement for dairy cows appears to have a toxic effect on ruminal microorganisms and was also found to reduce milk fat content (Franklin et al., 1999). Butyrivibrio fibrisolvens is one of the major microorganisms involved in microbial fatty acid alterations in the rumen. Maia et al. (2010) found, that when unsaturated fatty acids are incorporated into the microbial cell membrane of Butyrivibrio fibrisolvens, they increase the permeability of the membrane, negatively impacting the integrity of the cell. These authors identified this loss of cell integrity as a mechanism of PUFA toxicity and found that the highly unsaturated fish oil fatty acids, EPA and DHA, are very toxic to ruminal microorganisms. Protection of fish oil from hydrogenation should prevent its adverse effects on rumen function. Kitessa et al. (2001a) observed that the administration of protected tuna oil increased milk EPA and DHA concentrations without reducing the dry matter intake and milk yield of goats. In supplemented diets, tuna oil (protected and unprotected) constituted $3 \%$ of DM. The content of EPA and DHA in milk was $0.3 \%-0.5 \%$ and $1.01 \%-1.12 \%$, respectively. The rate of transfer of EPA and DHA to milk ranged from $3.5 \%$ to $7.6 \%$. Disregarding the practical and economic aspects of feeding cows with such high amounts of fish oil, one major problem may be concern over the sustainability of fish stocks. Few feeds are as rich in polyunsaturated fatty acids and marine algae are the only possible alternative (Givens et al., 2000). When supplementing cow diets with marine algae at $910 \mathrm{~g}$ per day, Franklin et al. (1999) concluded that they were effective in increasing milk DHA content, especially when the algae were protected with xylose. The concentration and yield of DHA in milk was increased by the inclusion of algae in the diet with respective yields of DHA of 0,3.2 and $4.9 \mathrm{~g} \cdot \mathrm{d}^{-1}$ for the control, unprotected and protected algae diet. The concentration of DHA in milk was $0,0.13$ and $0.22 \mathrm{~g} \cdot \mathrm{kg}^{-1}$ milk, respectively. Similar results were obtained by Glover et al. (2012). At the same time, however, the algae caused a significant decrease in dry matter intake and milk fat content.

Increasing the dietary supply of linolenic acid, from which long-chain unsaturated fatty acids (EPA and DHA) can be synthesized, could be one of the ways of increasing the concentration of these acids in cow milk fat. Rich sources of linolenic acid are grass and oil from some linseed varieties. Increasing the intake of linolenic acid by feeding fresh forage (Hebeisen et al., 1993) or protected linseed oil (Doreau et al., 1999) increases the supply of precursors of EPA and DHA to the mammary gland. Kalscheur et al. (1997) observed that a high-forage $\operatorname{diet}\left(600 \mathrm{~g} \cdot \mathrm{kg}^{-1}\right)$, compared with a low-forage one $\left(250 \mathrm{~g} \cdot \mathrm{kg}^{-1}\right)$, increased the intake of linolenic acid $\left(84 \mathrm{~g} \cdot \mathrm{d}^{-1}\right.$ vs $\left.58 \mathrm{~g} \cdot \mathrm{d}^{-1}\right)$. There was a small increase in the yield of linolenic acid in milk $\left(8.0 \mathrm{~g} \cdot \mathrm{d}^{-1} \mathrm{vs}\right.$ $\left.5.9 \mathrm{~g} \cdot \mathrm{d}^{-1}\right)$ when high-forage diets were fed, but the effect on EPA and DHA yields was not reported. A higher proportion of forages in the diet may, however, increase the ruminal biohydrogenation of PUFA, because this process is stimulated by higher $\mathrm{pH}$ and lower propionate production.

A study by DePeters et al. (1995) was designed to determine the possibility of increasing the EPA 
and DHA content of cow muscles and milk through selection of different genotypes, but no differences were found in the ratio of long-chain fatty acids among different breeds (Holstein, Brown Swiss $\times$ Holstein, Brown Swiss, Brown Swiss $\times$ Jersey and Jersey) fed the same diet. These results suggest that attempts to change the proportions of EPA and DHA in milk via genetics will be ineffective.

\section{Protection of fat against ruminal biohydrogenation}

Enriching cow diets with linolenic acid, EPA and DHA to increase the long-chain fatty acid content of milk entails some problems. The benefits of adding PUFA-rich fat to the diets of cows may be limited by its negative effect on fermentation in the rumen, mainly through reduction of the cellulolytic activity of rumen microflora. Supplemental fat may also cause rumen acidosis. The most important problem in terms of the possibility of enriching milk with EPA and DHA is, however, the extensive biohydrogenation of these acids in the rumen. This process can be avoided using different forms of protection against bacterial lipolysis, which determines subsequent biohydrogenation. By their very nature, fatty acids in oil seeds (e.g., linseed) are partially protected by protein when whole seeds are fed (Doreau et al., 1999). Another effective method is to coat the lipid with formaldehyde-treated protein (Chilliard et al., 2000). Goodridge et al. (2001) demonstrated that the presence of formaldehyde-protected linseed in rations caused a marked increase in omega-3 acids in milk fat. The linolenic acid content was significantly greater in the milk of cows fed protected lineseed (6.4\% vs $0.8 \%$ in the control). When using fish oil protected in this way, Gulati et al. (1999) did note a minimal increase in EPA and DHA transfer to goat's milk, but dry matter intake and milk fat content decreased. On the other hand, Kitessa et al. (2001a), who used casein-formaldehyde-protected tuna oil, noted considerable transfer of EPA and DHA from diet to goat's milk, with no deterioration in feed intake or milk yield. The rate of transfer of dietary EPA and DHA to milk ranged from 3.5\% to $7.6 \%$. In Poland, however, it is forbidden to use formaldehyde as a livestock feed additive.

Another method of decreasing ruminal biohydrogenation of fat is to heat feeds at a high temperature. A study by Strzetelski et al. (1993) showed that supplementing cow diets with rapeseed heated at $130^{\circ} \mathrm{C}$ increased omega-3 acids in milk, which points to the slowing down of ruminal biohydrogenation.

An effective method of preventing disturbances in rumen bacterial fermentation is to use calcium salts of fatty acids. These fats are not degraded in the neutral $\mathrm{pH}$ of the rumen and are well digested enzymatically in an acid environment. In a study by Elmeddah et al. (1991), calcium salts of palm oil had no adverse effect on rumen function, which was attributed to low dissociation in the rumen when the $\mathrm{pH}$ is 6-7. Nevertheless, the fatty acids of palm oil are saturated acids. Brzóska et al. (1999) demonstrated that feeding calcium salts of linseed and fish oil fatty acids in the form of the preparation Erafet considerably improved the dietary value of milk by increasing the proportion of polyunsaturated essential fatty acids. In his study, giving cows calcium salt from linseed oil at $0-960 \mathrm{~g} \cdot \mathrm{d}^{-1}$ resulted in an increase in PUFA $n-3$ in milk from 1.2 to $2.25 \mathrm{~g} \cdot 100 \mathrm{~g}^{-1}$ and an increase in synthesis from 9.6 to $20.1 \mathrm{~g} \cdot \mathrm{d}^{-1}$. Other studies (Ferlay et al., 1993; Castaneda-Gutierrez et al., 2007) showed that calcium salts of fatty acids are extensively hydrogenated in the rumen. This is probably associated with a rapid decline in ruminal $\mathrm{pH}$ post-feeding. The lack of a negative effect of calcium soaps on carbohydrate digestibility in the rumen may result from the fact that after fatty acid hydrogenation, ionized calcium increases adhesion of rumen bacteria to feed particles (Van Nevel and Demeyer, 1996).

Another way to protect fats against ruminal hydrogenation is to emulsify fish and marine animal oil with oil seeds. When emulsifying tuna oil with soyabean in vitro, Kitessa et al. (2001c) achieved 75\% protection against ruminal hydrogenation. Under in vivo conditions, however, protection was found to be slightly lower. Gulati et al. (2000) found the apparent efficiency of EPA and DHA transfer to be $29 \%$ and $15 \%$, respectively, when emulsifying tuna oil with rapeseed.

A somewhat newer method of protecting fatty acids against ruminal hydrogenation is to form fatty acyl amides. Jenkins (1995) showed that n-butylamine, which reacts with soyabean oil, ensures partial resistance of fatty acyl amides to ruminal biohydrogenation.

The another, easy method of protecting EPA and DHA from rumen biohydrogenation is to add fish oil in powdered form to the cow's feed. Gulati et al. (2003) showed that the use of fish oil protected from ruminal biohydrogenation by encapsulating the lipids in a matrix of rumen-inert protein leads to production of milk with enriched levels of DHA and EPA.

The process that determines fatty acid biohydrogenation is triglyceride lipolysis. A low rumen $\mathrm{pH}$ decreases the rate of lipolysis, thus, all $\mathrm{pH}$-lowering factors, such as feeding cereal, may enhance fatty 
acid protection. Low rumen $\mathrm{pH}$ decreases, however, the yield of bacterial protein as well as the rate and degree of fibre digestion. Since this procedure also negatively affects the health and welfare of dairy cows, intentional reduction of $\mathrm{pH}$ is not recommended as a method of protecting unsaturated fatty acids from ruminal biohydrogenation.

Lipolysis-inhibiting properties are also exhibited by certain antibiotics, in particular ionophores and amoxicillin, thus reducing the degree of fatty acid biohydrogenation (Van Nevel and Demeyer, 1995). Despite being effective, the antibacterial preparations used for this purpose are objectionable and will fail to gain public approval.

\section{Conclusions}

No reliable method for enriching cow's milk with omega-3 eicosapentaenoic (EPA) and docosahexaenoic (DHA) essential fatty acids has been found. Increasing the amounts of EPA and DHA or their precursor, linolenic acid, in cow diets has a limited effect due to the extensive biohydrogenation of these fatty acids in the rumen as well as the low uptake by the mammary gland. This is why the dietary manipulation of EPA and DHA content in cow's milk has limited impact. Feeding protected sources of these long-chain fatty acids significantly increases EPA and DHA contents in total milk fatty acids, although their absolute level is relatively low, generally below $10 \mathrm{~g} \cdot \mathrm{kg}^{-1}$ of fatty acids. Even with such low concentrations, however, milk can provide considerable amounts of EPA and DHA, which are needed to bring the $n-6$ to $n-3$ ratio in the modern human diet back into balance. In addition, supplementing cow diets with EPA and DHA increases the concentration of conjugated linoleic acid in milk, which is also nutritionally beneficial. Effectively increasing the EPA and DHA content of cow's milk requires further research. An appropriate fat supplement, an effective method of its protection from ruminal biohydrogenation, as well as a method for transferring absorbed EPA and DHA via blood circulation to make them easily absorbed by the mammary gland and incorporated into milk fat, are still waiting to be developed. The higher costs of producing such nutritionally enhanced milk should be compensated, however, by its price.

\section{References}

Abu-Ghazaleh A.A., Schingoethe D.J., Hippen A.R., Kalscheur K.F., 2003. Milk conjugated linoleic acid response to fish oil supplementation of diets differing in fatty acid profiles. J. Dairy Sci. 86, 944-953
Abu-Ghazaleh A.A., Schingoethe D.J., Hippen A.R., Kalscheur K.F., Whitlock L.A., 2002. Fatty acid profiles of milk and rumen digesta from cows fed fish oil, extruded soybeans or their blend. J. Dairy Sci. 85, 2266-2276

Akalin S., Gonc S., Unal G., 2006. Functional properties of bioactive components of milk fat in metabolism. Pakistan J. Nutr. 5, 194-197

Arienti G., Harrison F.A., Leat W.M., 1974. The lipase activity of sheep pancreatic juice. Quart. J. Exp. Physiol. Cogn. Med. Sci. 59, 351-359

Ashes J.R., Siebert B.D., Gulati S.K., Cuthbertson A.Z., Scott T.W., 1992. Incorporation of $n-3$ fatty acids of fish oil into tissue and serum lipids of ruminants. Lipids 27, 629-631

Brzóska F., Gasior R., Sala K., Zyzak W., 1999. Effect of calcium salts of fatty acids on yield and milk components (in Polish). Rocz. Nauk. Zoot. 26, 143-157

Cant J.P., Freeden A.H., Mclntyre T., Gunn J., Crowe N., 1997. Effect of fish oil and monoensin on milk composition of dairy cows. Can. J. Anim. Sci. 77, 125-131

Castaneda-Gutierrez E., de Veth M.J., Lock A. L., Dwyer D. A., Murphy K.D., Bauman D.E., 2007. Effect of Supplementation with calcium salts of fish oil on $\mathrm{n}-3$ fatty acids in milk fat. J. Dairy Sci. 90, 4149-4156

Chilliard Y., 1993. Dietary fat and adipose tissue metabolism in ruminants, pigs and rodents: a review. J. Dairy Sci. 76, 3897-3931

Chilliard Y., Doreau M., 1997. Effect of ruminal or postruminal fish oil supply on cow milk yield and composition. Reprod. Nutr. Develop. 37, 338-339

Chilliard Y., Ferlay A., Mansbridge R.M., Doreau R.M., 2000. Ruminant milk fat plasticity: nutritional control of saturated, polyunsaturated, trans and conjugated fatty acids. Ann. Zootech. 49, $181-205$

DePeters E., Medrano J.F., Reed B.A., 1995. Fatty acid composition of milk fat from three breeds of dairy cattle. Can. J. Anim. Sci. $75,267-269$

Doreau M., Chilliard Y., Relquin H., Demeyer D.I., 1999. Manipulation of milk fat in dairy cows. In: P.C. Garnsworthy, J. Wiseman (Editors). Recent Advences in Animal Nutrition. Nottingham University Press, Nottingham (UK), pp. 81-109

Doreau M., Ferlay A., 1994. Digestion and utilization of fatty acids by ruminants. Anim. Feed Sci. Tech. 45, 379-396

Elmeddah Y., Doreau M., Michalet-Doreau B., 1991. Interaction of lipid supply and carbohydrates in the diet of sheep with digestibility and ruminal digestion. J. Agr. Sci. 116, 437-445

EFSA J. (European Food Safety Authority Journal), 2012. Scientific opinion on the tolerable upper intake level of eicosapentaenoic acid (EPA), docosahexaenoic acid (DHA) and docosapentaenoic acid (DPA), Parma (Italy), 10 (7), 2815, pp.1-48

FAO/WHO, 1993. Fats and oils in human nutrition. Report of a joint expert consultation. FAO Food and Nutrition, Paper 57. Rome (Italy)

Ferlay A., Chabrot J., Elmeddah Y., Doreau M., 1993. Ruminal lipid balance and intestinal digestion by dairy cows fed calcium salts of rapeseed oil fatty acids or rapeseed oil. J. Anim. Sci. 71, 2237-2245

Franklin S.T., Martin K.R., Baer R.J., Schingoethe D.J., Hippen A.R., 1999. Dietary marine algae (Schizochytrium sp.) increases concentrations of conjugated linoleic, docosahexaenoic and transvaccenic acids in milk of dairy cows. J. Nutr. 129, 2048-2052

Givens D.I., Cottrill B.R., Davies M., Lee P.A., Mansbridge R.J., Moss A.R., 2000. Sources of n-3 polyunsaturated fatty acids additional to fish oil for livestock diets - a review. Nutr. Abstr. Rev. Ser. B 70, 1-19 
Glover K.E., Budge S., Rose M., Rupasinghe H.P.V., MacLaren L. Green-Johnson J., Fredeen A.H., 2012. Effect of feeding fresh forage and marine algae on the fatty acid composition and oxidation of milk and butter. J. Dairy Sci. 95, 2797-2809

Goodridge J., Ingalls J.R., Crow G.H., 2001. Transfer of omega-3 linolenic acid and linoleic acid to milk fat from flaxseed or Linola protected with formaldehyde. Can. J. Anim. Sci. 81, 525-532

Griinari J.M., Bauman D.E., 1999. Biosynthesis of conjugated linoleic acid and its incorporation into meat and milk in ruminants. In: M.P. Yurawecz, M.M. Mossoba, J.K.G. Kramer, M.W. Pariza, G.J. Nelson (Editors). Advances in Conjugated Linoleic Acid Research. Vol. 1. AOCS Press, Champaign, IL (USA), pp. 180-200

Gulati S.K., Ashes J.R., Ascott T.W., 1999. Hydrogenation of eicosapentaenoic and docosahexaenoic acids and their incorporation into milk fat. Anim. Feed Sci. Tech. 79, 57-64

Gulati S.K., Kitessa S.M., Asher J.R., Simos G.C., Wynn P.C., Fleck E., Scott T.W., 2000. Designing milk fat for the new Millennium by dietary strategies. Asian-Austr. J. Anim. Sci. 13, Suppl., 538-541

Gulati S.K., McGrath S., Wynn P.C., Scott T.W., 2003. Preliminary results on the relative incorporation of docosahexaenoic and eicosapentaenoic acids into cow's milk from two types of rumen protected fish oil. Int. Dairy J. 13, 339-343

Harfoot C.G., Hazlewood G.P., 1997. Lipid metabolism in the rumen. In: P.N. Hobson, C.S. Stewart (Editors). The Rumen Microbial Ecosystem. Stewart Published by Blackie Academic and Professional. London, pp. 382-419

Hebeisen D.F., Hoeflin F., Reusch H.P., Junker E., Lauterburg B.H., 1993. Increased concentrations of omega-3 fatty acids in milk and platelet rich plasma of grass-fed cows. Int. J. Vitam. Nutr. Res. 63, 229-233

Jenkins T.C., 1995. Butlysoyamide protects soybean oil from ruminal biohydrogenation: effects of butlysoyamide on plasma fatty acids and nutrient digestion in sheep. J. Anim. Sci. 73, 818-823

Kalscheur K.F., Teter B.B., Piperova L.S., Erdman R.A., 1997. Effect of dietary forage concentration and buffer addition on duodenal flow of trans-C18:1 fatty acids and milk fat production in dairy cows. J. Dairy Sci. 80, 2104-2114

Karmali R.A., 1989. N-3 fatty acids and cancer. Review. J. Intern. Med., Suppl. 731, 197-200

Keady T.W., Mayne C.S., Fitzpatrick D.A., 2000. Effects of supplementation of dairy cattle with fish oil on silage intake, milk yield and milk composition. J. Dairy Res. 67, 137-153

Kemp P., Lander D.J., 1984. Hydrogenation in vitro of a-linolenic acid to stearic acid by mixed cultures of pure strains of rumen bacteria. J. Gen. Microbiol. 130, 527-533

Kim E.J., Huws S.A., Lee M.R.F., Wood J.D., Muetzel S.M., Wallace R.J., Scollan N.D., 2008. Fish oil increases the duodenal flow of long chain polyunsaturated fatty acids and trans-11 18:1 and decreases 18:0 in steers via changes in the rumen bacterial community. J. Nutr. 138, 889-896

Kitessa S.M., Gulati S.K., Ashes J.R., Fleck E., Scott T.W., Nichols P.D., 2001a. Utilisation of fish oil in ruminants. II. Transfer of fish oil fatty acids into goats' milk. Anim. Feed Sci. Tech. 89, 201-208

Kitessa S.M., Gulati S.K., Ashes J.R., Fleck E., Scott T.W., Nichols P.D., 2001b. Utilization of fish oil in ruminants I. Fish oil metabolism in sheep. Anim. Feed Sci. Tech. 89, 189-199

Kitessa S.M., Gulati S.K., Ashes J.R., Scott T.W., Fleck E., 2001c. Effect of feeding tuna oil supplement protected against hydrogenation in the rumen on growth and n-3 fatty acid content of lamb fat and muscle. Aust. J. Agr. Res. 52, 433-437
Klein C., Jenkins T., 2011. Docosahexaenoic acid elevates trans-18:1 isomers but is not directly converted into trans-18:1 isomers in ruminal batch cultures. J. Dairy Sci. 94, 4676-4683

Kołodziejczyk M., 2007. Consumption of fish and fishery products in Poland - analysis of benefits and risks (in Polish). Rocz. Państw. Zakł. Hig. 58, 287-294

Konieczny S., 2010. The level of fish and fish preserves consuming at parents and children from super-basic schools in Szczecin (in Polish). Folia Pomer. Univ. Technol. Stetin. Oeconomica 284(61), 27-32

Kromhout D., 1989. Fish (oil) consumption and coronary heart disease. In: C. Galli, A.P. Simopoulos (Editors). Dietary $\omega 3$ and $\omega 6$ Fatty Acids. Biological Effects and Nutritional Essentiality. Plenum Publishing, New York (USA), pp. 273-282

Maia M.R.G., Chaudhary L.C., Bestwick C.S., Richardson A.J., McKain N., Larson T.R., Graham I.A., Wallace R.J., 2010. Toxicity of unsaturated fatty acids to the biohydrogenating ruminal bacterium, Butyrivibrio fibrisolvens. BMC Microbiol. 10, 52

Noguchi M., Rose D.P., Earashi M., Miyazaki I., 1995. The role of fatty acids and eicosanoid synthesis inhibitors in breast carcinoma. Review. Oncology 52, 265-271

Offer N.W., Speake B.K., Dixon J., Marsden M., 2001. Effect of fish-oil supplementation on levels of $(n-3)$ polyunsaturated fatty acids in the lipoprotein fractions of bovine plasma. Anim. Sci. 73, 523-531

Rose D.P., Connolly J.M., 1991. Effect of fatty acids and eicosanoid synthesis inhibitors on the growth of two human prostate cancer cell lines. Prostate 18, 243-254

Rymer C., Givens D.I., Wahle K.W.J., 2003. Dietary strategies for increasing docozahexaenoic acid (DHA) and eicosapentaenoic acid (EPA) concentrations in bovine milk: a review. Nutr. Abstr. Rev., Ser. B 73 (4), pp. 9R-25R

Sprecher H., 2000. Metabolism of highly unsaturated n-3 and n-6 fatty acids. Biochim. Biophys. Acta, 1486, 219-231

Strzetelski J., Ryś R., Stasiniewicz T., Lipiarska E., Stankiewicz B., 1993. Effect of heat-treated rapeseeds included to concentrate mixtures on cow performance, milk fat composition and rumen fermentation (in Polish). Rocz. Nauk. Zoot. 20, 107-121

Toral P.G., Frutos P., Hervás G., Gómez-Cortés P., Juárez M., de la Fuente M.A., 2010. Changes in milk fatty acid profile and animal performance in response to fish oil supplementation, alone or in combination with sunflower oil, in dairy ewes. J. Dairy Sci. 93, 1604-1615

Tsai W.S., Nagawa H., Kaizaki S., Tsuruo T., Muto T., 1998. Inhibitory effects of $n-3$ polyunsaturated fatty acids on sigmoid colon cancer transformants. J. Gastroenterol. 33, 206-212

Van Nevel C.J., Demeyer D.I., 1995. Lipolysis and biohydrogenation of soybean oil in the rumen in vitro: inhibition by antimicrobials. J. Dairy Sci. 78, 2797-2806

Van Nevel C.J., Demeyer D.I., 1996. Effect of pH on biohydrogenation of polyunsaturated fatty acids and their $\mathrm{Ca}$-salts by rumen microorganisms in vitro. Arch. Tierernähr. 49, 151-158

Wood J.D., Enser M., Fisher A.V., Nute G.R., Richardson R.I., Sheard P.R., 1999. Manipulating meat quality and composition. Proc. Nutr. Soc. $58,363-370$

Zymon M., Strzetelski J., Kowalczyk J., Osiegłowski S., 2007. The effects of linseed and rapeseed cultivars and of fish oil on the fatty acid profile of cow milk fat. J. Anim. Feed Sci. 16, Suppl.1, 70-74 